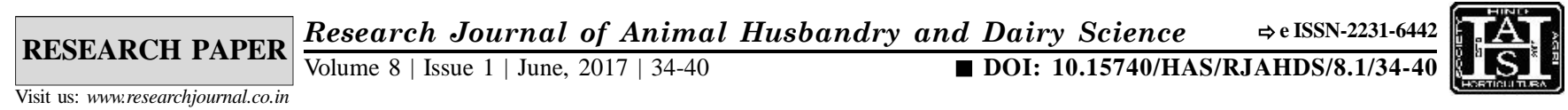

\title{
Studies on chemical quality of Sandesh
}

\author{
V. N. PATIL, R. M. KADAM, P. S. NAIK AND S.V. JOSHI
}

\begin{abstract}
India is the largest milk producing country in the world with 114.4 million tones milk production and per capital availability $268 \mathrm{~g} /$ day. Dairy in India has meant to our people since ancient days, milk production primary through the cow keeping and using the cow milk mainly for use of family and for religious rituals. Sandesh is the one of the most popular traditional milk products in Indian subcontinent. Pattern of milk production in India indicates that about 6 per cent of the milk produced is coagulated to produce Chhana. Out of this, about 80 per cent is used for manufacture of Sandesh. The efforts are made in the present investigation to add the value of Sandesh by incorporating the mango pulp @ 7.5 per cent, 15 per cent, 22.5 per cent and 30 per cent of weight of Chhana. The different physico-chemical properties were determined. It is concluded,the cow milk Chhana used for Sandesh preparation contained on an average 23.38 per cent fat, 45.37 per cent total solids, 17.33 per cent protein and 0.31 per cent acidity. Total solids content of Sandesh decreased significantly with increase in the level of mango pulp. The average values for control, 7.5, 15, 22.5 and 30 per cent levels of mango pulp were 75.27, 74.30, 73.31, 72.35 and 71.01 per cent total solids, respectively. With the increase in the level of mango pulp, there was significant decrease in fat content of Sandesh. protein content of Sandesh varied significantly with the values of 18.35, 17.89, 17.54, 17.21 and 16.89 per cent at control, 7.5, 15, 22.5 and 30 per cent level of mango pulp, respectively. With the increase in the level of mango pulp, there was significant decrease in protein content of Sandesh. Whereas With the increase in the level of mango pulp, there was significant increase in acidity of Sandesh.
\end{abstract}

KEY WORDS : Cow milk, Chhana, Citric acid, Mango pulp

HOW TO CITE THIS PAPER : Patil, V.N., Kadam, R.M., Naik, P.S. and Joshi, S.V. (2017). Studies on chemical quality of Sandesh. Res. J. Animal Hus. \& Dairy Sci., 8(1) : 34-40 : DOI: 10.15740/HAS/RJAHDS/8.1/34-40.

Address for correspondence :

V.N. Patil, Livestock Research Station (Dr. BSKKV), Nileli, Kudal, SINDHUDURG (M.S.) INDIA

Email : vishalpt139@gmail.com

Associated Authors':

R.M. Kadam, P. S. Naik and S.V. Joshi, Department of Animal Husbandry and Dairy Science, Dr. Balasheb Savant Konkan Krishi Vithyapeeth, Dapoli, RATNAGIRI (M.S.) INDIA 